\title{
Editorial Edição Especial 2009
}

Este número especial da revista Psicologia e Sociedade reúne 15 artigos em torno do tema Psicanálise: linguagem, experiência e utopia. A psicanálise tem tido presença importante no campo da prática, da pesquisa e do ensino em psicologia no Brasil e o fato da editoria desta revista acolher este número especial, evidencia o diálogo fértil que a psicologia social tem construído com o discurso psicanalítico. Se outro título fosse ainda possível para este número, poderíamos evocar um texto de juventude do poeta Rainer Maria Rilke "Notas sobre a melodia das coisas" onde esboça de forma poética um pensamento sobre a arte do encontro, a necessidade fundamental de escutar os bastidores de nosso mundo para sabermos um pouco mais em que direção podemos e devemos seguir. Sabemos que este é um grande desafio. Rilke inicia este pequeno texto justamente questionando de que vale um mundo de sonhos sem atos. Insiste ele: "é preciso se tornar um iniciador. Alguém que escreve uma primeira palavra ..."1 Os textos que aqui apresentamos ensaiam palavras de fronteiras, litorais, pois buscam construir diálogos com outros campos do conhecimento a partir da psicanálise. Em um tempo em que a máquina de fabricação do consentimento, como evoca Noam Chomsky, busca regular as formas de viver e de pensar, precisamos abrir furos nesta névoa de paralisia e construir outras possibilidades de futuro, o que implica evidentemente, uma prática social atenta ao sofrimento psíquico. As três palavras chaves que compõem o título deste número especial buscam justamente esta direção: linguagem, experiência e utopia como articuladores clínicos e políticos de um pensamento que quer escutar a melodia, por vezes, ruidosa de nossa época.

Os artigos deste número reúnem pesquisadores de inúmeras universidades brasileiras bem como do exterior (México e França) abrindo diálogos com outros grupos de pesquisa que se dedicam a pensar a relação Psicologia e Sociedade. Todos os artigos publicados nesse número seguiram o mesmo processo editorial dispensado aos artigos publicados nos números regulares. Agradecemos a acolhida da editoria da revista a esta proposta de publicação bem como a todos os consultores que com seus pareceres contribuíram para a qualidade científica da presente publicação. Esperamos que as ressonâncias deste número sejam frutíferas.

Edson Luiz André de Sousa (UFRGS) Maria Cristina Poli (UFRGS e UVA-RJ)

Cleci Maraschin (UFRGS) Anna Carolina Lo Bianco (UFRJ)

RILKE, Rainer Maria. Notes sur la melodie des choses. Paris, Éditions Allia, 2008, p.9 